\title{
A BLEND OF BIOASH AND GYPSUM UTILIZED FOR AGRO- ENVIRONMENTAL PURPOSES IN A SOIL INCUBATION EXPERIMENT
}

\author{
RÉKÁSI, M. ${ }^{1}$ - UZINGER, N. ${ }^{1 *}$ - ANTON, Á.D. ${ }^{2}$ - SZÉCSY, O ${ }^{1}$ - FÜLÖP, ${ }^{3}{ }^{3}-$ ANTON, A. ${ }^{1}$ \\ ${ }^{1}$ Institute for Soil Sciences and Agricultural Chemistry, Centre for Agricultural Research, \\ Hungarian Academy of Sciences \\ H-1022, Budapest, Herman Ottó út. 15, Hungary. \\ (phone: +36-1-212-2265; fax: +36-1-212-2265) \\ ${ }^{2}$ Department of Applied Biotechnology and Food Science, Budapest University of Technology \\ and Economics, \\ H-1111, Budapest, Szent Gellért tér 4., Hungary \\ ${ }^{3}$ Nitrogénmüvek Zrt. \\ H-8105 Pétfürdö, Hösök tere 14., Hungary \\ *Corresponding author \\ e-mail: uzinger.nikolett@agrar.mta.hu
}

(Received $18^{\text {th }}$ Nov 2013; accepted $14^{\text {th }}$ Aug 2014)

\begin{abstract}
Soil improver, nutrient supplier and heavy metal stabilizer effects of ash residue remaining after the process for $\mathrm{K}$ recovery was examined in a soil incubation model experiment using two soil types (acid sandy soil and neutral loam soil) at 4 ash residue dose levels $(0,1,3,5 \%)$. Possible environmental risks posed by its application were also studied by ecotoxicological assays. As the result of ash residue treatment alkalinity of the soils has been raised in all treatments. In the case of acid soil even the use of $1 \%$ of ash residue proved to be enough for neutralising the soil $\mathrm{pH}$. Ash residue is principally suitable for $\mathrm{K}$ and $\mathrm{P}$ supply and mostly in soils with poor nutrient content, where ash residue applied in $1 \%$ dose is able to increase the concentration of plant available $\mathrm{K}$ and $\mathrm{P}$ significantly. According to the results, the ash residue proved to be able to decrease the mobility of $\mathrm{Pb}$ and $\mathrm{Zn}$ which means that it can be an effective stabilizer in acid and neutral soils. Stabilization has probably occurred via adsorption. Based on the findings of the ecotoxicological assays, the use of $1 \%$ ash residue does not present substantial environmental risk.
\end{abstract}

Keywords: biomass ash, soil amelioration, fertilization, heavy metal stabilization, ecotoxicology

\section{Introduction}

Increasing importance of biomass combustion has raised problems related to the resulting ash as a by-product. Every year tens of thousands of tonnes of biomass ash (bioash) are produced in biomass power plants and heating plants. Handling and disposal of bioash as waste is costly and presents environmental risks. However, product manufacturing from bioash means an alternative enabling the utilization of this special waste. According to several studies the high $\mathrm{CaCO}_{3}$ content of bioash makes it suitable for the improvement of acid soils (Ulery et al., 1993; Muse and Mitchell, 1995; Meiwes 1995; Vance, 1996; Zang et al., 2002; Deydier et al., 2005; Vassilev et al., 2013). Because of its high nutrient content (firstly $K$ and P) it can be utilized as a nutrient source (Ohno and Erich, 1993; Fransman and Nihlgard, 1995; Vance, 1996; Demeyer et al., 2001; Bungart et al., 2001; Park et al., 2005; Ahmaruzzaman, 2010; Tan and Lagerkvist, 2011; Huotari et al., 2008) as well. Furthermore, due to their adsorption 
capacity combustion products could be applied for soil remediation purposes by decreasing heavy metal mobility in contaminated soils (Feng et al., 2004; Srivastava et al., 2006; Gruiz et al., 2009; Ahmaruzzaman, 2010; Vassilev et al., 2013).

Biomass ash is composed of porous carbon-containing particles and irregularly shaped mineral particles. More than $80 \%$ of bioash is below $1 \mathrm{~mm}$ in size (Etiegni and Campbell, 1991). Its main component is $\mathrm{CaCO}_{3}$. Density of bioash varies between 0.27 and $0.51 \mathrm{~g} / \mathrm{cm}^{3}$ (Muse and Mitchell, 1995). Alkalinity, acid neutralizing capacity of bioash is also significant (Demeyer et al., 2001).

Macroelement content of bioash varies over a wide range with the following median values: $0.06 \% \mathrm{~N}, 0.42 \% \mathrm{P}, 18 \% \mathrm{Ca}, 0.97 \% \mathrm{Mg}$ and $2.27 \% \mathrm{~K}$ (Vance, 1996). Still, it is the applicability of bioash to be used as $\mathrm{K}$ and $\mathrm{P}$ supplier that might be of huge significance in plant production.

Similarly to macroelements, microelement concentration of bioash also shows great variation. According to the analyses of several bioashes with different origins the highest mean concentration among microelements was that of $\mathrm{Mn}(4370 \mathrm{mg} / \mathrm{kg})$, followed by $\mathrm{Zn}(443 \mathrm{mg} / \mathrm{kg}), \mathrm{Cu}(75 \mathrm{mg} / \mathrm{kg}), \mathrm{B}(110 \mathrm{mg} / \mathrm{kg})$, and $\mathrm{Mo}(15 \mathrm{mg} / \mathrm{kg})$. Concentration of $\mathrm{As}, \mathrm{Ni}, \mathrm{Cr}$ and $\mathrm{Pb}$ varied between 23 and $65 \mathrm{mg} / \mathrm{kg}$, whereas regarding non-essential trace elements the concentrations of Se and $\mathrm{Hg}(<0,5 \mathrm{mg} / \mathrm{kg})$, as well as Cd and Co $(<10 \mathrm{mg} / \mathrm{kg}$ ) proved to be low (Someshwar, 1996).

In spite of being reasonable, application of bioash in plant production should be carried out cautiously due to its composition that might include organic and mineral pollutants. Besides contaminating both soils and groundwaters it can also affect their acidity, chemical composition and biodiversity in a disadvantageous way (Vassilev et al., 2013).

The possibilities of the re-utilisation of biomass ashes have been studied worldwide including industrial and agricultural purposes (Lima et al., 2012; Huang et al., 2011; Huang et al., 1992). One of the latest potential options is to use it as a raw material for $\mathrm{K}$ fertilizers. According to the method that is now being improved potassium is extracted from herbaceous biomass ash with $80-90^{\circ} \mathrm{C}$ water, thereafter solution and residue (ash residue) are separated by filtration. Following the addition of sulphuric acid the solution is condensed and potassium-sulphate is gained as the end product. Through processing the residue with gypsum and carbon-dioxide, a soil improver with high $\mathrm{Ca}$ and $\mathrm{K}$ content is produced. This resulting blend of ash residue and gypsum (hereafter "ash residue") enriched with $\mathrm{Ca}$ contains significant amounts of macro- and microelements. Regarding its basic properties, ash residue has similar qualities to that of untreated biomass ash (Table 1). It should be noticed that data from literature show great variances. Concentration values of several components of the ash residue analysed in our experiment were found to be of similar order of magnitude to those published before with the exception of $\mathrm{Mn}$ and $\mathrm{Na}$ for which we obtained lower values.

Blends of ash and gypsum have already been tested as construction materials (Sadique et al., 2013). In present experiment the soil improver, nutrient supplier and heavy metal stabilizer effects of the ash residue described previously were studied in a soil incubation model experiment. Possible environmental risk posed by its application was examined as well, using ecotoxicological methods. According to literature data favourable overall effects of the material could be expected. However, it should be considered that by containing significant amounts of potentially toxic elements, ash residue can cause environmental risk. These negative effects have already been demonstrated on different aquatic test organisms (Barbosa et al., 2013). On the grounds 
of these, principal questions to be answered are the following: (i) whether the ash residue is applicable for all of the three aforementioned purposes and (ii) whether its utilization is limited by the potential toxicity caused by its composition. Based on the literature, toxicological knowledge on the application of ash originating from the combustion of herbaceous plants as a soil improver is limited. This work might also provide new findings to this topic.

Table 1. $\mathrm{pH}$ and element composition ( $\mathrm{mg} / \mathrm{kg}$ ) of different biomass ash and ash-residue

\begin{tabular}{|c|c|c|c|c|c|}
\hline Parameter & $\begin{array}{c}\text { Wood ash } \\
(\text { Etiegni and } \\
\text { Campbell 1991)* }\end{array}$ & $\begin{array}{r}\text { Wood ash } \\
\text { (Huang et } \\
\text { al., 1992)* }\end{array}$ & $\begin{array}{c}\text { Reed canary- } \\
\text { grass ash } \\
\text { (Paulrud et al., } \\
\text { 2001) }\end{array}$ & $\begin{array}{c}\text { Switchgrass } \\
\text { ash } \\
\text { (Vassilev et } \\
\text { al., 2013) }\end{array}$ & Ash residue \\
\hline $\begin{array}{l}\text { Particle size } \\
\text { distribution }\end{array}$ & $80 \%:<1 \mathrm{~mm}$ & & & & $\begin{array}{c}18 \%: 2-0.05 \mathrm{~mm} \\
82 \%: 0.05-0.002 \\
\mathrm{~mm}\end{array}$ \\
\hline Density & $0.27-0.51 \mathrm{~g} / \mathrm{cm}^{3}$ & & & & $0.41 \mathrm{~g} / \mathrm{cm}^{3}$ \\
\hline pH & 9-13.5 & & & & 9.5 \\
\hline $\mathbf{N}$ & 600 & 900 & & & 0 \\
\hline $\mathbf{P}$ & 14000 & 6900 & 11800 & & 44050 \\
\hline $\mathbf{S}$ & 4455 & 6800 & & & 28570 \\
\hline $\mathbf{C a}$ & 317400 & 109400 & 18200 & & 154600 \\
\hline Mg & 22500 & 16200 & 7400 & & 37390 \\
\hline $\mathbf{K}$ & 41300 & 28600 & 28300 & & 91510 \\
\hline $\mathbf{N a}$ & 3400 & 1600 & 1800 & & 101 \\
\hline Al & 23650 & 13000 & 3200 & & 1222 \\
\hline $\mathrm{Fe}$ & 19500 & 3300 & & & 1563 \\
\hline Mn & 6693 & 3470 & & 872 & 222 \\
\hline Zn & 700 & 794 & & 103 & 576 \\
\hline $\mathrm{Cu}$ & 145 & 78 & & 66 & 388 \\
\hline $\mathbf{B a}$ & 8 & 127 & & & 64 \\
\hline $\mathbf{P b}$ & 130 & 66 & & & 1.2 \\
\hline $\mathbf{N i}$ & 47 & 12 & & 37 & 42 \\
\hline $\mathrm{Cr}$ & 86 & 14 & & 49 & 6.1 \\
\hline Cd & 21 & 3 & & 9.8 & 3.6 \\
\hline
\end{tabular}

*In: Demeyer et al., 2001

\section{Materials and methods}

\section{Experimental design}

Topsoil (0-0.2 m depth) samples were used in order to examine the effects of ash residue on soil properties and on heavy metal mobility. The samples were taken from two soil types, one from an acid sandy soil (Nyírlugos, EOV coordinates: 874919, 265291) and the other from a neutral loam soil (Gyöngyös, EOV coordinates: 716000, 271195). These types were chosen with the purpose of studying the effects of ash residue on two soils that differ from each other basically regarding both their alkalinity 
and colloid content. Soils were contaminated artificially except for one case in which it was left in its natural state, as follows:

1. uncontaminated soil sample: acid soil (Nyírlugos) (USS),

2. acid soil (Nyírlugos) contaminated with $\mathrm{Pb}$ and $\mathrm{Zn}$ salts $\left(\mathrm{Pb}\left(\mathrm{NO}_{3}\right)_{2}\right.$ and $\left.\mathrm{ZnSO}_{4}\left(7 \mathrm{H}_{2} \mathrm{O}\right)\right)+400 \mathrm{mg} \mathrm{Pb}$ and $800 \mathrm{mg} \mathrm{Zn} / \mathrm{kg}$ of soil (LZSS),

3. loam soil (Gyöngyös) contaminated with mine refuse (11\%) (Gyöngyösoroszi) (MRLS),

4. loam soil (Gyöngyös) contaminated with communal sewage sludge (Gödöllö) (SSLS).

Ash residue was mixed to the soil in the following ratios: control, 1, 3 and $5 \mathrm{~m} / \mathrm{m} \%$. Each treatment was performed in three replicates. Total element contents of the soil mixtures are summarized in Table 2.

Table 2. Total (cc. $\mathrm{HNO}_{3}+\mathrm{HCl}$ soluble) element concentrations of the four soils ( $\mathrm{mg} / \mathrm{kg}$ )

\begin{tabular}{ccc|c|c|c|c}
\hline Element & USS & LZSS & MRLS & SSLS & limit values* \\
\hline Ca & 576 & 507 & 13683 & 18153 & - \\
$\mathbf{K}$ & 1543 & 1513 & 10644 & 11713 & - \\
$\mathbf{P}$ & 383 & 365 & 2925 & 5520 & - \\
$\mathbf{M g}$ & 1012 & 1012 & 5432 & 6095 & - \\
$\mathbf{S}$ & 117 & 380 & 1607 & 1008 & - \\
$\mathbf{Z n}$ & 17.4 & $\mathbf{5 9 9}$ & $\mathbf{2 3 5}$ & $\mathbf{5 9 1}$ & 200 \\
$\mathbf{C u}$ & 5 & 5 & $\mathbf{8 5}$ & $\mathbf{1 9 5}$ & 75 \\
$\mathbf{B a}$ & 32.0 & 37.1 & $\mathbf{3 0 6}$ & $\mathbf{4 0 7}$ & 250 \\
$\mathbf{N i}$ & 7.08 & 6.85 & $\mathbf{5 1 . 1}$ & $\mathbf{4 6 . 6}$ & 40 \\
$\mathbf{C r}$ & 10.2 & 9.8 & $\mathbf{7 5}$ & $\mathbf{1 9 8}$ & 75 \\
$\mathbf{A s}$ & 1.23 & 0.99 & $\mathbf{4 3 . 2}$ & 11.0 & 15 \\
$\mathbf{C d}$ & 0.032 & 0.042 & $\mathbf{1 . 1 4}$ & $\mathbf{3 . 4 0}$ & 1 \\
$\mathbf{C o}$ & 3.14 & 2.98 & 16.0 & 13.2 & 30 \\
$\mathbf{P b}$ & 5.12 & $\mathbf{4 1 8}$ & $\mathbf{1 6 4}$ & 48.1 & 100 \\
$\mathbf{M o}$ & 0.127 & 0.186 & 2.25 & 1.13 & 7 \\
Se & $<\mathrm{dl}$ & $<\mathrm{dl}$ & $<\mathrm{dl}$ & 0.953 & 1 \\
\hline
\end{tabular}

$<\mathrm{dl}$ : under detection limit. $\mathrm{dl} \mathrm{Hg:} 0.12 \mathrm{mg} / \mathrm{kg}$; dl Se: 0.6 ; *contamination limit values for soils in joint decree No. 6/2009; Bold characters indicate values above limit.

Each pot was filled with $1 \mathrm{~kg}$ of soil. In the case of the second soil mixture concentrations of $\mathrm{Pb}$ and $\mathrm{Zn}$ in the soil were four times higher than the limit values of the Hungarian regulations (Government Joint Decree No. 6/2009. (IV. 14.) KvVMEüM-FVM on limit values established for the protection of groundwater and the geological medium). The levels of sewage sludge and mine refuse dosage were calculated in a way that the concentrations of some elements in the soil exceed the contamination limit values (according to the Joint Decree No. 6/2009. (IV. 14.) KvVMEüM-FVM) many times over (Table 2). Different contaminants were applied in order to have a better understanding of heavy metal stabilization processes these materials are supposed to take part in.

Element composition and some properties of the ash residue are presented in table 1. It can be seen that it had a $\mathrm{pH}\left(\mathrm{H}_{2} \mathrm{O}\right)$ value of 9.5 , contained $28.3 \% \mathrm{CaCO}_{3}$ and no nitrogen, whereas its ammonium lactate (AL) soluble $\mathrm{K}_{2} \mathrm{O}$ and $\mathrm{P}_{2} \mathrm{O}_{5}$ contents were 
$10.5 \%$ and $3.7 \%$, respectively. Some parameters of the soil mixtures can be found in Table 3.

Table 3. Selected properties of the soil samples

\begin{tabular}{c|c|c|c|c|c}
\hline Soil & $\mathbf{p H}\left(\mathbf{H}_{\mathbf{2}} \mathbf{O}\right)$ & $\mathbf{C a C O}_{\mathbf{3}} \%$ & $\mathbf{O M} \%$ & $\begin{array}{c}\text { Upper limit of } \\
\text { plasticity }\end{array}$ & CEC meq/100g \\
\hline USS & 5.04 & 0.00 & 0.92 & 33 & 1.76 \\
LZSS & 4.19 & 0.00 & 0.97 & 33 & 1.67 \\
MRLS & 7.04 & 0.26 & 4.44 & 45 & 27.9 \\
SSLS & 7.05 & 0.56 & 6.05 & 53 & 34.1 \\
\hline
\end{tabular}

All contaminants $(\mathrm{Pb}$ and $\mathrm{Zn}$ solution, mine refuse and sewage sludge) and the different doses of ash residue were added to the soils at the same time. After homogenisation, the mixtures were filled into pots and incubated for 1 month. The mixtures were wetted to $70 \%$ of field capacity of the soils.

\section{Methods}

\section{Analyses of soil parameters and soil chemical properties}

The soil was analysed according to the following standards: $\mathrm{pH}\left(\mathrm{H}_{2} \mathrm{O}\right)-$ ISO 10390:2005, humus content - ISO 14235:1998, $\mathrm{CaCO}_{3}$ content - ISO 10693:1995, cation exchange capacity (CEC) - ISO 11260:1994; aqua regia extract, distilled water 1:10 extract, $\mathrm{NH}_{4}$-acetate + EDTA-soluble element fraction - MSZ 21470-50:2006, ammonium acetate buffer extract - MSZE 21420-31;2006, ammonium-lactate soluble element content - MSZ 20135:1999, particle size distribution - MSZ-08-0205:1978.

\section{Ecotoxicological tests}

All microbiological and ecotoxicological assays were performed in three replications. The number of aerobic heterotrophic colony forming units was determined in wet soil samples. The soil samples for the Sinapis alba root and shoot growth inhibition test were dried, ground and passed through a $2 \mathrm{~mm}$ sieve.

Aerobic heterotrophic colony-forming units. The soil microbial biomass and the number of viable microorganisms can be used to assess soil quality and are relatively easy to determine using routine methods such as plate count tests (Benedetti and Dilly, 2006). In this experiment different soil dilutions in sterile distilled water were inoculated into an appropriate media ensuring that after the incubation period one colony is formed from one living cell. The method was described by Lorch et al. (1995). The number of aerobic heterotrophic microorganisms was expressed as colony forming units (CFUs) per $\mathrm{g}$ of soil.

Sinapis alba root and shoot growth inhibition test. In the presence of toxic substances the germination rate and the root and shoot growth of Sinapis alba (white mustard) plants are inhibited (OECD, 2006). The test was performed as described by Leitgib et al. (2007). Five grams of soil were measured out into a $10 \mathrm{~cm}$ diameter Petri-dish, wetted to its water holding capacity and 20 seeds with over $90 \%$ germination ability were placed on the soil surface. The samples were incubated at $23^{\circ} \mathrm{C}$ in the dark for three days. The length of roots and shoots were measured manually with a ruler. The growth inhibition was expressed as follows: $\mathrm{I}(\%)=(\mathrm{C}-\mathrm{L}) / \mathrm{C} * 100$, where I means the 
inhibition \%, C means the length of shoot or root in the control (OECD soil), while L means the length of shoot or root of Sinapis alba in the sample. The artificial soil recommended by the OECD Guideline 207, (OECD, 1984) (content: 70\% sand, 20\% clay, $10 \%$ peat) was used as the uncontaminated control.

\section{Statistical Analysis}

The data were analysed for treatment effects using one-way analysis of variance (ANOVA) on the main treatments (time period, different layers). Significant differences between the treatment means were calculated by the LSD (least significant difference) test at $\mathrm{p}<0.05$. In the correlation analysis the asterisks, *, ** and $* * *$ indicate significance at $\mathrm{p}<0.05,0.01$ and 0.001, respectively. Statistica v.9 (StatSoft Inc.) software was used for all the statistical evaluations.

\section{Results}

\section{Soil amelioration and nutrient supply}

As presented in Table 4, the $\mathrm{pH}$ value has increased by more than 3 units in the case of the light-textured acid sandy soil. Correspondingly the application of $3 \%$ of ash residue made the sandy soils alkaline, whereas $1 \%$ of it (equivalent to $10 \mathrm{t} / \mathrm{ha} \mathrm{CaCO}_{3}$ )

Table 4. Some soil properties in function of ash residue treatment

\begin{tabular}{|c|c|c|c|c|c|c|}
\hline \multirow{2}{*}{ Soil } & \multirow{2}{*}{$\begin{array}{c}\text { Ash- } \\
\text { residue \% }\end{array}$} & \multirow{2}{*}{$\mathbf{p H}\left(\mathrm{H}_{2} \mathrm{O}\right)$} & $\mathrm{CaCO}_{3}$ & AL- $\mathrm{K}_{2} \mathrm{O}$ & AL-P $\mathbf{P}_{2} \mathbf{O}_{5}$ & CEC \\
\hline & & & $\mathrm{w} / \mathrm{w} \%$ & $\mathrm{mg} / \mathrm{kg}$ & mg/kg & meq/100g \\
\hline \multirow{5}{*}{ USS } & 0 & 5.00 & - & 65 & 138 & 1.76 \\
\hline & 1 & 7.64 & 0.09 & 793 & 952 & 3.83 \\
\hline & 3 & 8.48 & 0.40 & 2504 & 2521 & 4.72 \\
\hline & 5 & 8.69 & 0.82 & 3972 & 3680 & 5.84 \\
\hline & $\mathbf{L S D}_{5 \%}$ & 0.1 & 0.05 & 198 & 312 & 1.29 \\
\hline \multirow{5}{*}{ LZSS } & $\mathbf{0}$ & 4.19 & - & 70 & 151 & 1.67 \\
\hline & 1 & 6.93 & - & 852 & 960 & 3.15 \\
\hline & 3 & 8.43 & 0.36 & 2620 & 2286 & 4.06 \\
\hline & 5 & 8.70 & 0.69 & 4200 & 3565 & 4.72 \\
\hline & $\mathbf{L S D}_{5 \%}$ & 0.08 & 0.04 & 438 & 186 & 0.96 \\
\hline \multirow{5}{*}{ MRLS } & $\mathbf{0}$ & 7.04 & 0.26 & 884 & 3748 & 27.9 \\
\hline & 1 & 7.62 & 0.51 & 1680 & 4461 & 29.7 \\
\hline & 3 & 8.05 & 0.90 & 3477 & 6111 & 25.6 \\
\hline & 5 & 8.20 & 1.52 & 5140 & 7340 & 25.5 \\
\hline & LSD $_{5 \%}$ & 0.05 & 0.11 & 169 & 373 & n.s. \\
\hline \multirow{5}{*}{ SSLS } & $\mathbf{0}$ & 7.05 & 0.56 & 936 & 7070 & 34.1 \\
\hline & 1 & 7.50 & 0.75 & 1800 & 7869 & 35.3 \\
\hline & 3 & 7.94 & 1.13 & 3633 & 8727 & 33.5 \\
\hline & 5 & 8.13 & 1.56 & 5526 & 9873 & 30.7 \\
\hline & $\mathbf{L S D}_{5 \%}$ & 0.06 & 0.19 & 221 & 762 & 2.9 \\
\hline
\end{tabular}

n.s. = not significant 
proved to be enough to neutralize them. It can be stated that regarding the experimental acid sandy soils, the $\mathrm{pH}$ value of 6.8 being desired when liming can be reached by using an ash residue dose of $15 \mathrm{t} / \mathrm{ha}$. $\mathrm{CaCO}_{3}$ contents were also found to increase significantly in both soils and following all treatments. The acid sandy soil had the smallest CEC, while the largest was that of the loam soil contaminated with sewage sludge. Regarding the acid sandy soil, ash residue treatment has increased CEC compared to the control in all of the cases, whereas no significant change was observed for loam soil contaminated with mine refuse. As for the loam soil contaminated with sewage sludge, 5\% ash residue treatment has lowered the CEC statistically in comparison with the no ash treatment. This might be originated in the dilution effect (Table 4).

In the case of present experiment addition of $1 \%$ ash residue resulted in the 12-fold increase of AL-soluble $\mathrm{K}$ and the 7-fold increase of $\mathrm{P}$ in the acid sandy soil compared to the control (Table 4). In the case of the $3 \%$ ash residue treatment this surplus was 38fold for AL soluble $\mathrm{K}$ and 18 -fold for AL soluble $\mathrm{P}$, while with the addition of $5 \%$ ash residue it reached 61-fold and 27-fold $\mathrm{AL}-\mathrm{K}_{2} \mathrm{O}$ and $\mathrm{AL}-\mathrm{P}_{2} \mathrm{O}_{5}$ content of the control soil, respectively. With regards to the neutral loamy soil a 2 -fold increase was observed in the case of AL soluble $\mathrm{K}$ with the use of $1 \%$ ash residue, whereas $\mathrm{P}$ was not found to increase considerably compared to the control. By adding 3\% of ash residue this surplus proved to be 4-fold regarding $\mathrm{AL}-\mathrm{K}_{2} \mathrm{O}$ and about 1.5-fold for $\mathrm{AL}-\mathrm{P}_{2} \mathrm{O}_{5}$. The addition of $5 \%$ ash residue led to a fold change of 6 in the case of $A L-\mathrm{K}_{2} \mathrm{O}$ content, whereas in the case of $\mathrm{AL}-\mathrm{P}_{2} \mathrm{O}_{5}$ content the difference was almost two-fold only in the soil contaminated with mine refuse. The changes in $\mathrm{K}$ and $\mathrm{P}$ concentrations were significant. Based on these results the ash residue may be suitable primarily for $\mathrm{K}$ and $\mathrm{P}$ supply.

\section{Heavy metal stabilisation}

Outstanding heavy metal stabilization effect was only observed in the $\mathrm{Pb}$ and $\mathrm{Zn}$ contaminated acid sandy soil (Table 5) of what the most probable cause is its low organic matter content and low metal binding capacity. In the uncontaminated sandy soil the plant available $\mathrm{Pb}$ and $\mathrm{Zn}$ concentrations increased significantly due to the element content of ash residue. However, even in this soil the water soluble concentrations decreased. Regarding the neutral loam soil the decrease in the solubility of $\mathrm{Zn}$ was proven statistically in the acetate and water soluble fractions but the ash increased the plant available $\mathrm{NH}_{4}$-acetate + EDTA soluble $\mathrm{Pb}$ and $\mathrm{Zn}$ concentrations.

Table 5. Soluble fractions of $\mathrm{Pb}$ and $\mathrm{Zn}$ extracted by different solvents in an acid sandy soil

\begin{tabular}{|c|c|c|c|c|c|c|c|}
\hline \multirow[t]{2}{*}{ Soil } & \multirow[t]{2}{*}{$\begin{array}{c}\text { Ash- } \\
\text { residue } \\
\%\end{array}$} & $\begin{array}{c}\mathrm{NH}_{4^{-}} \\
\text {acetate + } \\
\text { EDTA } \\
\text { soluble } \\
\end{array}$ & $\begin{array}{l}\mathrm{NH}_{4^{-}} \\
\text {acetate } \\
\text { soluble }\end{array}$ & $\begin{array}{c}\text { Water } \\
\text { soluble }\end{array}$ & $\begin{array}{c}\mathrm{NH}_{4^{-}} \\
\text {acetate }+ \\
\text { EDTA } \\
\text { soluble } \\
\end{array}$ & $\begin{array}{l}\mathrm{NH}_{4-} \\
\text { acetate } \\
\text { soluble }\end{array}$ & $\begin{array}{r}\text { Water } \\
\text { soluble }\end{array}$ \\
\hline & & \multicolumn{3}{|c|}{$\mathrm{Pb} \mathrm{mg} / \mathrm{kg}$} & \multicolumn{3}{|c|}{ Zn mg/kg } \\
\hline \multirow{7}{*}{ USS } & 0 & 1.90 & $<\mathrm{dl}$ & 0.100 & 1.6 & 1.84 & 0.899 \\
\hline & 1 & 2.43 & $<\mathrm{dl}$ & 0.081 & 5.7 & 3.53 & 0.519 \\
\hline & 3 & 2.54 & $<\mathrm{dl}$ & 0.072 & 14.7 & 5.94 & 0.231 \\
\hline & 5 & 2.79 & $<\mathrm{dl}$ & 0.060 & 21.9 & 7.09 & 0.060 \\
\hline & $\mathbf{L S D}_{\mathbf{5} \%}$ & 0.55 & & n.s. & 1.7 & 1.31 & 0.276 \\
\hline & 0 & 323 & 125 & 4.35 & 649 & 452 & 287 \\
\hline & 1 & 307 & 25 & 2.64 & 627 & 413 & 11 \\
\hline
\end{tabular}




\begin{tabular}{cccccccc} 
LZSS & $\mathbf{3}$ & 263 & 9 & 1.45 & 590 & 386 & 2 \\
& $\mathbf{5}$ & 278 & 6 & 0.47 & 580 & 353 & 1 \\
& LSD $_{\mathbf{5} \%}$ & n.s. & 19 & 0.82 & 60 & 34 & 56 \\
\hline \multirow{4}{*}{ MRLS } & $\mathbf{0}$ & 26.7 & $<\mathrm{dl}$ & $<\mathrm{dl}$ & 73 & 11.8 & $<\mathrm{dl}$ \\
& $\mathbf{1}$ & 27.3 & $<\mathrm{dl}$ & $<\mathrm{dl}$ & 85 & 8.8 & $<\mathrm{dl}$ \\
& $\mathbf{3}$ & 24.1 & $<\mathrm{dl}$ & $<\mathrm{dl}$ & 87 & 7.0 & $<\mathrm{dl}$ \\
& $\mathbf{5}$ & 19.7 & $<\mathrm{dl}$ & $<\mathrm{dl}$ & 90 & 3.8 & $<\mathrm{dl}$ \\
& LSD $_{\mathbf{5} \%}$ & 1.5 & & & 7 & 1.5 & \\
\hline \multirow{3}{*}{ SSLS } & $\mathbf{0}$ & 19.8 & $<\mathrm{dl}$ & $<\mathrm{dl}$ & 314 & 16.3 & 0.256 \\
& $\mathbf{1}$ & 19.4 & $<\mathrm{dl}$ & $<\mathrm{dl}$ & 314 & 16.7 & 0.801 \\
& $\mathbf{3}$ & 17.4 & $<\mathrm{dl}$ & $<\mathrm{dl}$ & 306 & 10.9 & 0.107 \\
& $\mathbf{5}$ & 15.7 & $<\mathrm{dl}$ & $<\mathrm{dl}$ & 312 & 7.7 & 0.147 \\
& LSD $_{\mathbf{5} \%}$ & 1.7 & & & n.s. & 2.3 & 0.395 \\
\hline
\end{tabular}

n.s. $=$ not significant; $<\mathrm{dl}=$ under detection limit

\section{Toxicology}

\section{Aerobic heterotrophic colony-forming units (CFU)}

Aerobic heterotrophic cell number proved to be the lowest in the case of the uncontaminated acid sandy soil and it was the highest in the loam soil contaminated with sewage sludge (Fig. 1).

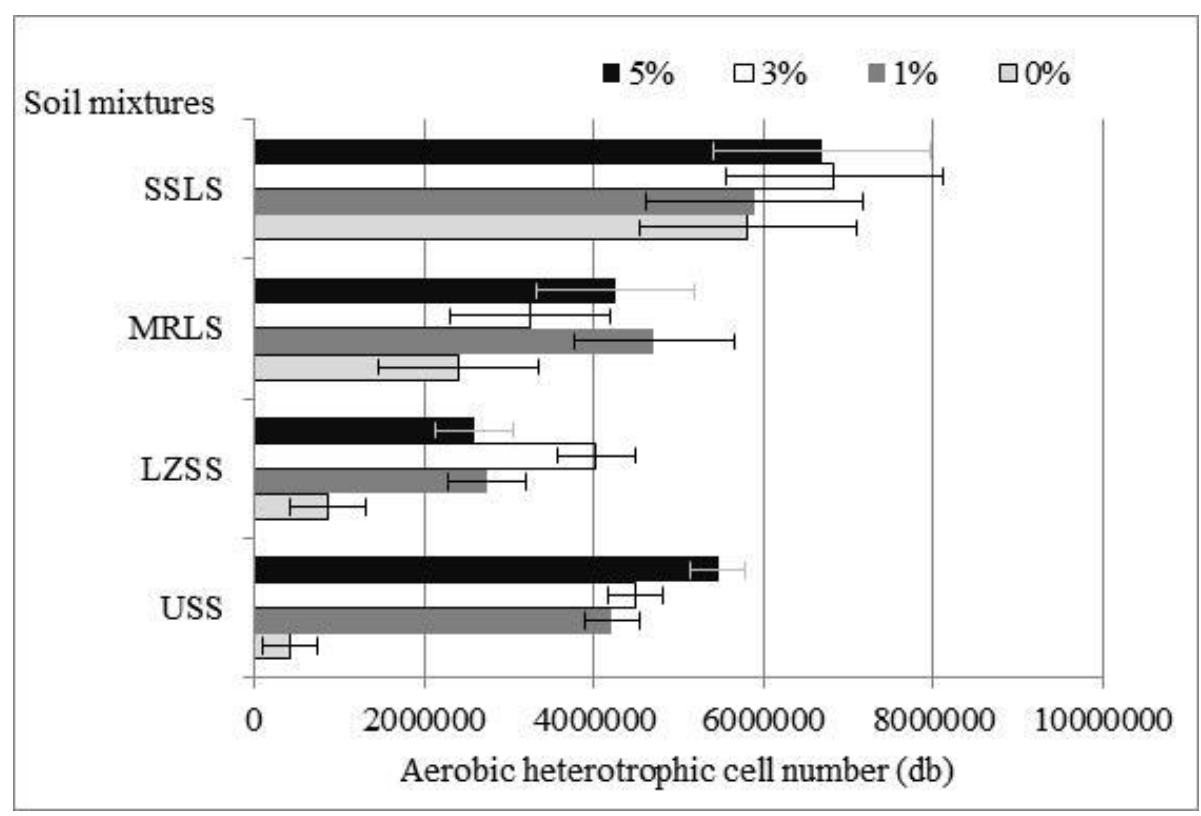

Figure 1. Aerobic heterotrophic cell number changes of soil mixtures in function of ash residue treatments

It was also found that compared to the soil without ash treatment, cell number has increased significantly as a result of ash residue treatment both in the contaminated and in the uncontaminated acid sandy soils as well as in the neutral loam soil contaminated

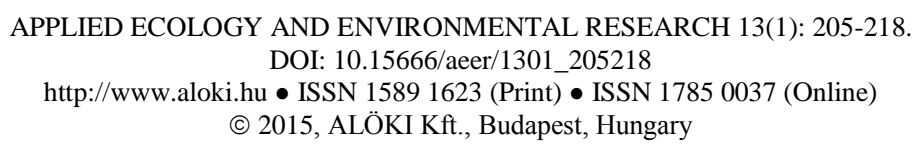


with mine refuse. Increase of ash residue dose to $3 \%$ and further to $5 \%$ was able to raise the aerobic heterotrophic cell number only in some cases.

\section{Sinapis alba root and shoot growth inhibition test}

The results in Table 6 show that the ash residue had both stimulating and inhibiting effects on the growth of Sinapis alba root and shoot growth depending on the soil type and contamination. Mentioned effects were definitely positive only on the lead and zinc contaminated sandy soil where each load level resulted in growth stimulation. Inhibition occurred in the case of other soils on both shoot and root elongation but in most cases only above a load of $1 \%$.

Table 6. Results of the Sinapis alba growth inhibition test

\begin{tabular}{|c|c|c|c|c|c|}
\hline Soil & $\begin{array}{c}\text { Ash-residue } \\
\%\end{array}$ & $\begin{array}{l}\text { Root length } \\
\text { (mm) }\end{array}$ & $\begin{array}{l}\text { Root growth } \\
\text { inhibition \% }\end{array}$ & $\begin{array}{l}\text { Shoot length } \\
\quad(\mathrm{mm})\end{array}$ & $\begin{array}{l}\text { Shoot growth } \\
\text { inhibition \% }\end{array}$ \\
\hline \multirow{5}{*}{ USS } & 0 & 24.0 & 0.0 & 13.1 & 0 \\
\hline & 1 & 17.2 & 28.4 & 14.5 & -10.8 \\
\hline & 3 & 11.7 & 51.7 & 10.7 & 20.1 \\
\hline & 5 & 7.4 & 68.3 & 5.9 & 53.5 \\
\hline & $\mathbf{L S D}_{\mathbf{5} \%}$ & 5.5 & 16.4 & 4.2 & 25 \\
\hline \multirow{5}{*}{ LZSS } & 0 & 4.1 & 0 & 4.1 & 0 \\
\hline & 1 & 13.7 & -237 & 15.4 & -276 \\
\hline & 3 & 11.9 & -189 & 10.0 & -144 \\
\hline & 5 & 7.1 & -74 & 5.4 & -36 \\
\hline & $\mathbf{L S D}_{\mathbf{5} \%}$ & 2.7 & 81.1 & 2.4 & 46 \\
\hline \multirow{5}{*}{ MRLS } & O & 12.2 & 0 & 12.7 & 0.0 \\
\hline & 1 & 11.6 & 3.3 & 15.0 & -18.1 \\
\hline & 3 & 10.2 & 14.9 & 14.5 & -18.9 \\
\hline & 5 & 7.3 & 39.4 & 9.6 & 26.0 \\
\hline & $\mathbf{L S D}_{\mathbf{5} \%}$ & 2.4 & 19.4 & 4.4 & n.s. \\
\hline \multirow{5}{*}{ SSLS } & O & 14.2 & 0.0 & 16.6 & 0.0 \\
\hline & 1 & 14.6 & -3.5 & 18.3 & -10.2 \\
\hline & 3 & 9.8 & 30.8 & 14.3 & 14.1 \\
\hline & 5 & 9.3 & 33.9 & 13.4 & 18.8 \\
\hline & $\mathbf{L S D}_{\mathbf{5} \%}$ & 2.3 & 16.9 & 4.0 & 24.5 \\
\hline
\end{tabular}

n.s. = not significant

\section{Discussion}

Based on the results ash residue treatment might be suitable to replace high-dose liming in the case of soils similar to those included in this experiment, in accordance with earlier findings (Ulery et al., 1993; Muse and Mitchell, 1995; Park et al., 2012). Because of the adsorption capacity of bioash, it was important to investigate what effect the ash residue treatment has on the CEC of the soils (Feng et al, 2004; Srivastava et al., 2006; Vassilev and Vassileva, 2007; Umamaheswaran and Batra, 2008). The ash residue treatment increased the adsorption capacity of the sandy soil,

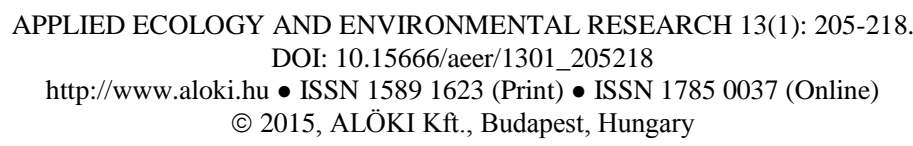


thus may improve the nutrient balance of similar soils. However, the higher (5\%) dose levels of ash residue may decrease the CEC of heavier textured soils due to the dilution effect (Table 4).

Based on literature data and regarding macroelements, biomass ash contains significant amounts of potassium and also has a relatively high phosphorous content with a mean of almost $0.5 \%$ (Vance, 1996; Fransman and Nihlgard, 1995). It contains large concentrations of microelements as well. Contrarily, according to some previous findings, with the addition of bioash to soil the solubility and availability of $\mathrm{Fe}, \mathrm{Mn}, \mathrm{Zn}$ and $\mathrm{Cu}$ decreased owing to the increased $\mathrm{pH}$ (Clapham and Zibliske, 1992; Krejsl and Scanlon, 1996). The biomass ashes proved to be suitable $\mathrm{P}$ and K suppliers for different cultivars (Schiemenz and Eichler-Löbermann, 2010; Kikamägi et al., 2013).

The effect of stabilisation is only presented by the concentration values of $\mathrm{Pb}$ and $\mathrm{Zn}$ in the four soil mixtures. Outstanding heavy metal stabilisation effect was only observed in the $\mathrm{Pb}$ and $\mathrm{Zn}$ contaminated acid sandy soil (Table 5) which might be explained by its low organic matter content and metal binding capacity. Chemical stabilizers/immobilizers can reduce the mobility of metals through adsorption, the formation of complexes or precipitation (Kumpiene et al., 2008). As shown in table 3, ash residue has increased the CEC of the acid sandy soil.

In the contaminated acid sandy soil the stabilizing effect of ash residue was the most observable on distilled water and ammonium-acetate buffer extractions, the former is representative for the easily mobilisable fraction while the latter for exchangeable cations (Tessier, 1979). The combination of $\mathrm{NH}_{4}$-acetate and EDTA is a much stronger extractant than the two mentioned due to the complex forming agent of EDTA which is able to make coordinated metal ions extractable as well (Schnitzer and Khan, 1978; Stevenson, 1982; Ram and Raman, 1984; Peijnenburg et al., 2007). Regarding this extraction stabilization effect of fly ash was not or only very slightly detected, therefore it can be assumed that (owing to the properties of ash residue as well) immobilization occurred via adsorption.

In the case of sewage sludge contaminated loam soil the CEC decreased in function of the amount of ash residue added, thus the observed stabilisation in the case of water and acetate soluble $\mathrm{Zn}$ concentration can be traced back to the precipitation of zincphosphate due to the $\mathrm{P}$ content of ash residue (Crannell et al., 2000; Theodoratos et al., 2002; Diyab et al., 2003).

Based on the above information the ash residue may reduce the element solubility by two ways: increasing the CEC and precipitating the metals into less soluble phosphorus salts. Thus, it is a possible stabilisation agent.

Although microbial count is not a direct measure of activity in soils, it is indicative of soil microbial viability (Bossert and Kosson, 1997) which is in relation with the organic matter and nutrient content of the soils (Table 2 and Table 3) (Kanazawa and Filip, 1986; Torsvik and Øvreås, 2002; Maron et al., 2006). Despite that favourable effects of bioash on soil microflora were described previously (Fritze et al., 2000), they were not observable in the soil contaminated with sewage sludge. The positive impacts of ash residue (Fig. I) can be explained by its following features: its capacity to provide good air and moisture supply, the fact that it increases the adsorption surface due to its particle composition, and that it decreases the biological availability of heavy metals by their stabilization (Nielsen et al., 2002; Dombos and Szalkai, 2004; Gillert et al., 2009).

The results of the Sinapis alba ecotoxicologcal test on uncontaminated sandy and contaminated loam soils are partly in accordance with results of similar experiments in 
literature. Rikala and Jozefek (1990) found that wood ash application in lover rates may increase the germination but higher doses (over $5 \mathrm{t} / \mathrm{ha}$ ) have negative effect on it. Similarly, Singh et al. (1997) demonstrated that fly ash application in low rates insignificantly increased the germination of bean (Vicia faba) which was inhibited at the rate of $30 \%$. In our experiment the slightly positive effect was insignificant in contrast to the inhibition on higher ash residue application rates. Thus, the nutrient content of ash residue did not promote the shoot and root growth but in higher doses its potentially toxic element content inhibited these processes. In contrary, on the contaminated sandy soil the ash residue successfully promoted the shoot end root growth due to the stabilisation of $\mathrm{Pb}$ and $\mathrm{Zn}$ contaminants.

\section{Conclusions}

Due to its alkaline $\mathrm{pH}$ and high (nearly $30 \%$ ) $\mathrm{CaCO}_{3}$-content, ash residue as a soil improver has significantly raised the $\mathrm{pH}$ of the studied soils. Even $1 \%$ dose of ash residue proved to be enough to turn the acid soil into neutral. The ash residue is mainly suitable for nutrient supply, primarily in the soils with poor nutrient content where ash residue applied in $1 \%$ dose is able to increase the concentration of plant available $\mathrm{K}$ and $\mathrm{P}$ significantly. We successfully demonstrated the capacity of ash residue to decrease the solubility of $\mathrm{Pb}$ and $\mathrm{Zn}$ in both the acid sandy and the neutral loam soils, which means that it is an appropriate stabilizer in the acidic environment. Stabilization has probably occurred via adsorption and precipitation. Based on the findings of the ecotoxicological assays, the use of $1 \%$ ash residue does not present substantial environmental risk.

For the establishment of real ways of utilization of ash residue pilot-plant and largescale field experiments are needed with the application of complex technology evaluation methods (material balance; cost-effectiveness analysis; description of risks).

Acknowledgement. This work was supported by the National Innovation Office (BIO_HAM2_TECH_08-A4/2-2008-0175) and by the János Bolyai Research Scholarship of the Hungarian Academy of Sciences.

\section{REFERENCES}

[1] 6/2009. (IV. 14.) (2009). KvVM-EüM-FVM common order about the standard limits and measurement of contamination for the protection of underground water and geological medium. (In Hungarian) - Magyar Közlöny 51: 14398-14414.

[2] Ahmaruzzaman, M. (2010): A review on the utilization of fly ash. - Prog Energy Combust 36: 327-363.

[3] Barbosa, R., Dias, D., Lapa, N., Lopes, H., Mendes, B. (2013): Chemical and ecotoxicological properties of size fractionated biomass ashes. - Fuel Processing Technology 109: 124-132.

[4] Benedetti, A., Dilly, O. (2006): Introduction. - In Bloem et al. (eds.) Mocrobial methods for assessing soil quality, CABI Publishing, Wallingford 3-15.

[5] Bossert, I.D., Kosson, D.S. (1997): Methods for measuring hydocarbon biodegradation in soils. - In: Hurst C.J., Knudsen G.R., McInerney M.J., Stetzenbach M.V. (eds) Manual of Environmental Microbiology, ASM Press, Washinton DC 738-745.

[6] Bungart, R., Huttl, R.F. (2001): Production of biomass for energy in post-mining landscapes and nutrient dynamics. - Biomass Bioenergy 20: 181-187.

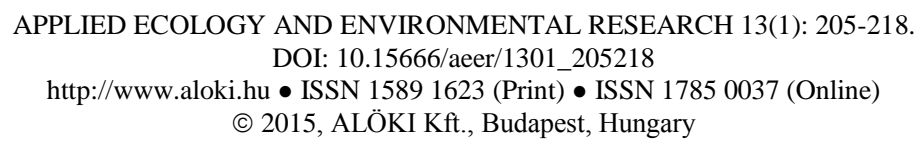


[7] Clapham, W.M., Zibilske, L.M. (1992): Wood ash as a liming amendment. - Commun. Soil. Sci. Plant Anal. 23: 1209-1227.

[8] Crannell, B.S., Eighmy, T.T., Krzanowski, J.E., Eusden, JrD., Shaw, E.L., Francis, C.A. (2000): Heavy metal stabilization of municipal solid-waste combustion bottom ash using soluable phophate. - Waste Management 20: 135-148.

[9] Demeyer, A., Voundi Nkana, J.C., Verloo, M.G. (2001): Characteristics of wood ash and influence on soil properties and nutrient uptake: an overview. - Biores. Technol. 77: 287295.

[10] Deydier, E., Guilet, R., Sarda, S., Sharrock, P. (2005): Physical and chemical characterisation of crude meat and bone meal combustion residue: "waste or raw material?"' - J Hazard Mater, B121: 141-148.

[11] Diyab, C., Julliot, F., Dumat, C., Morin, G., Benedetti, M., Mariotti, A. (2003): Study of the influence of phosphate amendents on soil - plant transfer of $\mathrm{Pb}$ for various plants. 8th International FZK/TNO Conference on Contaminated Soil CONSOIL 03, 12-16 May 2003., Gent, Proceedings 2342-2345.

[12] Dombos, M., Szalkai, T. (2004): Indication models in soil ecology. (In Hungarian) Agrokémia és Talajtan, 53:181-194.

[13] Etiegni, L., Campbell, A.G. (1991): Physical and chemical characteristics of wood ash. Biores. Technol. 37: 173-178.

[14] Feng, Q., Lin, Q., Gong, F., Sugita, S., Shoya, M. (2004): Adsorption of lead and mercury by rice husk ash. - J Colloid Interf Sci. 278:1-8.

[15] Food and Drug Administration (1987): Seed Germination and Root Elongation, Environmental Technical Assessment Document 406, Center for Food Safety and Applied Nutrition, Center for Veterinary Medicine, Washington, D. C.

[16] Fransman, B., Nihlgard, B. (1995): Water chemistry in forested catchments after topsoil treatments with liming agents in South Sweden. Water Air Soil Pollut. 85: 895-900.

[17] Fritze, H., Perkiömäki, J., Saarela, U., Katainen, R., Tikka, P., Yrjälä, K., Karp, M., Haimi, J., Romantschuk, M. (2000): Effect of Cd-containing wood ash on the microflora of coniferous forest humus. - FEMS Microbiology Ecology 32: 43-51.

[18] Gillert, K.E., Witter, E., McGarth S.P. (2009): Heavy metals and soil microbes. - Soil Biology and Biochemistry 41:2031-2037.

[19] Gruiz, K., Vaszita, E., Siki, Z., Feigl, V., Fekete F. (2009): Complex environmental risk management of a former mining site. - Land Contamination and Reclamation 17: 357369.

[20] Huang, H., Campbell, A.G., Folk, R., Mahler, R.L. (1992): Wood ash as a soil additive and liming agent for wheat. Field studies. - Commun. Soil Sci. Plant Anal. 23: 25-33.

[21] Huang, J.H., Hsu, S.H., Wang, S.L. (2011): Effects of rice straw ash amendment on Cu solubility and distribution in flooded rice paddy soils. Journal of Hazardous Materials 186: 1801-1807.

[22] Huotari, N., Tillman-Sutela, E., Pasanen, J., Kubin, E. (2008): Ash-fertilization improves germination and early establishment of birch (Betula pubescens Ehrh.) seedlings on a cutaway peatland. - Forest Ecology and Management 255: 2870-2875.

[23] ISO 10390:2005 Soil quality -- Determination of pH. ISO TC/SC: TC 190/SC 3, ICS:13.080.10.

[24] ISO 10693:1995 Soil quality -- Determination of carbonate content -- Volumetric method. TC/SC: TC 190/SC 3, ICS:13.080.10.

[25] ISO 11260:1994 Soil quality -- Determination of effective cation exchange capacity and base saturation level using barium chloride solution. ISO TC/SC: TC 190/SC 3, ICS: 13.080 .10

[26] ISO 14235:1998 Soil quality -- Determination of organic carbon by sulfochromic oxidation. TC/SC: TC 190/SC 3, ICS:13.080.10.

[27] Kanazawa, S., Filip, Z. (1986): Distribution of micro-organisms, total biomass, and enzyme activities in different particles of brown soil. - Microb. Ecol. 12: 205-212. 
[28] Kikamägi, K., Ots, K., Kuznetsova, T. (2013): Effect of wood ash on the biomass production and nutrient status of young silver birch (Betula pendula Roth) trees on cutaway peatlands in Estonia. - Ecological Engineering 58: 17-25.

[29] Krejsl, J. A., Scanlon, T.M. (1996): Evaluation of beneficial use of wood-fired boiler-ash on oat and bean growth. - J. Environ. Qual. 25: 950-954.

[30] Kumpiene, J., Lagerkvist, A., Maurice, C. (2008): Stabilization of As, Cr, Cu, Pb and Zn in soil using amendents - review. - Waste Management 28: 215-225.

[31] Leitgib, L., Kálmán, J., Gruiz, K. (2007): Comparison of bioassays by testing whole soil and their water extract from contaminated sites. - Chemosphere 66: 428-434.

[32] Lima, A.T., Ottosen, L.M., Ribeiro A.B. (2012): Assessing fly ash treatment: Remediation and stabilization of heavy metals. - Journal of Environmental Management 95: S110-S115.

[33] Lorch, H.J., Benckieser, G., Ottow, J.C.G. (1995): Basic methods for counting microorganisms in soil and water. - In: Alef, K., Nannipieri, P. (eds) Methods in Applied Soil Microbiology and Biochemistry, Academic Press, London 146-161.

[34] Maron, P.A., Schimann, H., Ranjard, L., Brothier, E., Domenach, A.M., Lensi, R., Nazaret, S. (2006): Evaluation of quantitative and qualitative recovery of bacterial communities from different soil types by density gradient centrifugation. - European Journal of Soil Biology 42: 65-73.

[35] Meiwes, K.J. (1995): Application of lime and wood ash to decrease acidification of forest soils. - Water Air Soil Pollut. 85: 143-152.

[36] MSZ 20135:1999. Determination of the soluble nutrient element content of the soil. (In Hungarian) Hungarian Standard Association, Budapest

[37] MSZ 21420-31:2006. Characterization of wastes. Part 31: Ammonium acetate puffer extract for physical-, chemical and ecotoxicological characterisation. (In Hungarian) Hungarian Standard Association, Budapest

[38] MSZ 21470-50:2006. Environmental testing of soils. Determination of total and soluble toxic element, heavy metal and chromium (VI) content. (In Hungarian) Hungarian Standard Association, Budapest

[39] MSZ-08-0205:1978. Determination of physical and hydrophysical properties of soils.(In Hungarian) Hungarian Standard Association, Budapest

[40] Muse, J.K., Mitchell, C.C. (1995): Paper mill boiler-ash and lime byproducts as soil liming materials. - Agron. J. 87: 432-438.

[41] Nielsen, N.M., Winding, A., Binnerup, S., Hansen B.M., Kroer N. (2002): Microorganisms as indicators of soil health. - National Environmental Research Institute, Ministry of Environment, Denmark 21-25.

[42] OECD Earthworm, acute toxicity tests. (1984): OECD-guideline for testing of chemicals no. 207. Paris

[43] OECD Terrestial plant test: Seedling emergence and seedling growth test. (2006): OECD guideline for testing of chemicals no. 208. Paris

[44] Ohno, T., Erich, M.S. (1993): Incubation-derived calcium carbonate equivalence of papermill boiler-ashes derived from sludge and wood sources. - Environ. Pollut. 79: 175180.

[45] Park, B.B., Yanai, R.D., Sahm, J.M., Lee D.K., Abrahamson, L.P. (2005): Wood ash effects on plant and soil in a willow bioenergy plantation. - Biomass Bioenergy 28: 355365.

[46] Park, N.D., Rutherford, P.M., Thring, R.W., Helle S.S. (2012): Wood pellet fly ash and bottom ash as an effective liming agent and nutrient source for rye grass (Lolium perenne L.) and oats (Avena sativa). - Chemosphere 86: 427-432.

[47] Paulrud, S., Nilsson, C., Öhman, M. (2001): Reed canary-grass ash composition and its melting behaviour during combustion. - Fuel 80: 1391-1398. 
[48] Peijnenburg, W. J.G.M., Zablotskaja, M., Vijver, M. (2007): Monitoring metal sin terrestrial environments within a bioavailability framework and a focus on soil extraction. - Ecotoxicology and Environmental Safety 67: 163-179.

[49] Ram, N., Raman, K.V. (1984): Stability constants of complexes of metals with humic and fulvic acids under non-acid-conditions. - Zeitschrift für Pflanzenernährung und Bodenkunde 147: 171-176.

[50] Rikala, R., Jozefek, H. (1990): Effect of dolomite lime and wood ash on peat substrate and development of tree seedlings. - Silva Fenn. 24:323-334.

[51] Sadique, M., Al-Nageim, H., Atherton, W., Seton, L., Dempster N. (2013): Mechanochemical activation of high-Ca fly ash by cement free blending and gypsum aided grinding. - Construction and Building Materials, 43: 480-489.

[52] Schiemenz, K., Eichler-Löbermann, B. (2010): Biomass ashes and their phosphorus fertilizing effect on different crops. - Nutrient Cycling in Agroecosystems 87: 471-482.

[53] Schnitzer, M, Khan S. (1978): Soil organic matter. Elsevier Scientific Pub. Co., New York 47-53.

[54] Singh, S. N., Kulshreshtha, K., Ahmad K. J. (1997): Impact of fly ash soil amendment on seed germination, seedling growth and metal composition of Vicia faba L. - Ecological Engineering 9:203-208.

[55] Someshwar, A.V. (1996): Wood ash and combination wood-fired boiler ash characterization. - J. Environ. Qual. 25: 962-972.

[56] Srivastava, V.C., Mall, I.D., Mishra, I.M. (2006): Equilibrium modelling of single and binary adsorption of cadmium and nickel onto bagasse fly ash. - Chem Eng J. 117: 79-91.

[57] Stevenson, F.J. (1982): Humus Chemistry. John Wiley and Sons, New York 24-58.

[58] Tan, Z., Lagerkvist, A. (2011): Phosphorus recovery from the biomass ash: a review. Renew Dust Energy Rev. 15: 3588-3602.

[59] Tessier, A., Campbell, P.G., Bisson, M. (1979): Sequential extraction procedures for the specification of particulate trace metals. - Anal. Chem. 5: 844-855.

[60] Theodoratos, P., Papassiopi, N., Xenidis, A. (2002): Evaluation of monobasic calcium phosphate for the immobilization of heavy metals in conatminated soils from Lavrion. Journal of Hazardous Material 94:135-146.

[61] Torsvik, V., Øvreås, L. (2002): Microbial diversity and function in soil:from genes to ecosystems. - Curr. Opin. Microbiol. 5: 240-245.

[62] U. S. Environmental Protection Agency (1985): Toxic Substances Control Act Test Guidelines; Final Rules, Federal Register,50, 797.1050, 797.1075, and 797.1060

[63] Ulery, A.L., Graham, R.C., Amrhein, C. (1993): Wood-ash composition and soil pH following intense burning. - Soil Sci. 156: 358-364.

[64] Umamaheswaran, K., Batra, V.S. (2008): Physico-chemical characterisation of Indian biomass ashes. - Fuel 87: 628-638.

[65] Vance, E.D. (1996): Land application of wood-fired and combination boiler ashes: an overview. - J. Environ Qual. 25: 937-944.

[66] Vassilev S., Baxter, D., Andersen L.K., Vassileva, C. (2013): An overview of the composition and application of biomass ash. Part 2. Potential utilisation, technological and ecological advantages and challenges. - Fuel 105: 19-39.

[67] Vassilev, S., Vassileva, C. (2007): A new approach for the classification of coal fly ashes based on their origin, composition, properties, and behaviour. - Fuel 86: 1490-1512.

[68] Zhang, F.S., Yamasaki, S., Nanzyo, M. (2002): Waste ashes for use in agricultural production: I. Liming effect, contents of plant nutrients and chemical characteristics of some metals. - Sci Total Environ 284: 215-25. 